\title{
Exploring Millennial Leadership Development: An Evidence Assessment of Information Communication Technology and Reverse Mentoring Competencies
}

\author{
Alissa E. Harrison \\ University of Maryland University College, Upper Marlboro, United States \\ Tel: 1-703-764-5918Ｅ-mail: Alissa.Harrison@muse-technologies.com
}

Received: Jan. 17, 2017 Accepted: Jan. 25, $2017 \quad$ Published: Feb. 19, 2017

doi:10.5296/csbm.v4i1.10615 URL: http://dx.doi.org/10.5296/csbm.v4i1.10615

\begin{abstract}
An essential element of a firm's competitiveness is the ability to attract, retain, and develop high potential employees. To build organizations that promote innovative leadership, development requires forward-thinking direction from the upper-most levels of organization management. Currently, many executives adhere to a traditional model when developing leaders who serve the organization's goals. A systematic review of empirical studies was conducted to address the question, how can managers use innovator competencies to affect developing innovative millennial leaders? Rapid evidence assessment offered a methodology for gathering and assessing evidence to determine the need for future research. Eleven primary studies were identified and a systematic review suggests that information computer technology and reverse mentoring promote horizontal competency development. The research also indicates that information computer technology and reverse mentoring encourage vertical or stages of leadership competency development that influence innovation. Findings from the systematic review suggest that generational characteristics are associated with information computer technology and reverse mentoring. In combining core competency theory with generational cohort theory, this study offers insights for organizational leaders in developing future innovator workforce leaders. Information computer technology and reverse mentoring for millennials in today's competitive organizational environment could serve to bridge the gap between needed leadership competencies and building needed innovator skills in the millennial cohort. This review contributes to theory by extending the understanding of organizational innovation through developing millennial leader competencies. Future research should investigate how other competencies might factor into the position organizations take in the development of a more strategic and innovative workforce.
\end{abstract}

Keywords: Millennial, Leadership Development, Innovation, Cohort Theory, Competency 
In discussing innovative management with forward-thinking executives, Gary Hamel asks, "How do you build organizations that merit the gifts of creativity, passion, and initiative" (Barsh, 2008, p. 3) when the traditional model merely asks individuals to serve the organizational goals? Though the intent of the article responds to the growing need for a new leadership model, the strategy transcends managing creative-thinking people. Undeniably, the highly talented are less likely to put up with an overly prescriptive hierarchical model and opt for decision-making that is more peer-based (Barsh, 2008, p. 6). This transition will become more of an issue with the entry of the millennial leaders into the workforce.

Given the burgeoning millennial workforce population over the past decade, this cohort will undoubtedly outnumber baby boomer workers in 2017 and will outpace all generational groups by 2020 (Quenqua, 2015). This upsurge will require changes in the way organizations deal with the employee talent pool. It is a shift in human resource management that concerns many business leaders because it portends a gap in the talent pool currently generated by today's U.S. colleges and universities as millions of millennials come of age and enter the workforce. According to a recent survey, $87 \%$ of C-suite executives claim that today's graduates lack essential workforce skills (Northeastern News, 2014). This perception has many organizations reviewing existing practices to prepare for this significant shift in the workforce composition.

Changes in management practice can transform the way in which businesses conduct leadership development for millennials. In describing the predilections of individuals born between 1980 and 2000, millennials tend to be more likely to find a solution and remain with a company than preceding generations (Emeagwaili, 2011, p. 25; Howe \& Strauss, 2007). In fact, millennials look to businesses to drive innovation and thereby enable organizational progress (DTTL, 2015). Accordingly, many millennials factor a company's business strategy and acumen for integrating innovation into their decision-making process when evaluating how the company treats employees. Additionally, technological changes introduced during the past few decades, how millennials integrate technology into daily activities and in their business environment tends to merge lifestyle and work for this innovative cohort. To address these looming challenges in leadership development, this paper reviews available evidence on leader development competencies to reveal innovator capabilities that influence millennial leader development.

Assimilating innovative capabilities offers opportunities to develop leadership competencies. Practitioners and researchers often reference a skills gap to reflect the difficulties many leaders have when trying to secure qualified personnel. In reviewing Schumpeter's (1934) earlier work, Hill \& Rothaermel (2003) suggest that smaller firms are more likely to be sources of innovation (p. 260). As depicted in recent innovative competency models, it would appear that employers value a variety of workforce skills, such as creative and enterprise thinkers, perceptive integrators, resourceful forecasters, and change management agents (Boyd, 2011). Furthermore, for many forward-thinking organizations, thinking critically, problem-solving, communicating, organizing, learning ability, and applying capabilities to the real-world are some of the skills purported as necessary for an innovative workforce (Boyd, 2011; Hill \& Rothaermel, 2003). With Generation X representing approximately 16\% 
of the workforce, coupled with the increasing retirement of baby boomers, employers will be looking to millennials to fill the impending leadership gaps (Brack, 2012, p. 2). Building an innovative competency mindset is key to developing strategic leaders and filling impending leadership gaps.

Potential leaders are often identified, selected, and trained using traditional leader development methodologies. Evidence suggests that face-to-face or classroom-led pedagogy modalities typically do not align with millennial training needs and preferences (Gentry, Griggs, Deal, Mondore, \& Cox, 2011, p. 41). Considering the effects of competency on leadership development, research needs to focus on how companies can realize their innovative organizational objectives when developing future leaders. In understanding whether generational characteristics factor in the development of leaders, traditional as well as contemporary approaches should be considered. In essence, planning leadership development for the millennial generation should reflect workplace-centric factors to enhance efficacy when defining future leader development programs. In that way, strategic innovator development may offer firms a competitive leadership edge in the marketplace. Contextually, this paper examines leadership development of millennials through the lens of the prevailing competency theory to respond to the research question, how can managers use innovator competencies to affect developing innovative millennial leaders? Conducting a review of evidence via a rapid evidence assessment (REA) of leader development competencies might reveal how innovator competencies factor in developing millennial leaders.

\section{Literature Review}

Extant competency research has theoretical roots in economics, social sciences, and psychology. Building on the works of earlier economists, Schumpeter (1950) researched competency through an economic lens (p. 139). By proposing that testing should be intelligence based, McClelland (1973) elevated the competency framework and added a psychological dimension. In particular, McClelland formally introduced the competency concept view to identify those psychological factors that align competency with work or life-related outcomes (p. 9). Most scholars classify competencies as inherent knowledge, skills, capabilities, attitudes, or intellectual strategies (McLagan, 1996, p. 62). To place boundaries around the numerous interpretations of competency found in the literature, this paper uses Prahalad \& Hamel's (1990) definition of the core competency of a firm to frame the discussion on competency. By bringing the disparate disciplines into one analytical frame, the author was able toexplore linkages from the traditional economics view of competency through to practices used by organizations to develop leaders.

Not only are there many definitions of competency found in the literature, but there are also various approaches used to frame and make sense of competencies. In fact, Day's (2001) initial research defined several core competencies that highlight the theoretical evolution of leadership development. The primary emphasis in leadership development is on using and building interpersonal competencies (Day, 2001, p. 585). In particular, Day’s research focuses on several management practices: 360-degree feedback, executive coaching, mentoring and networking, job assignments, and action learning are all practices that build 
interpersonal competency (Day, 2001, p. 581). Associating best practice approaches in defining leadership development with innovative competenciesprovides a framework for developing millennial leaders.

\subsection{Theoretical Framework: Defining Competency}

The inability to operationalize and thereby define competency tends to impede research. Often, the understanding of capabilities and competencies presents confusion because of the inconsistent use of these terms in literature. Prahalad \& Hamel (1990) use the terms competency and capability interchangeably when describing the corporate-wide technological skills that enable employee agility in their ability toadapt proactively to competitive opportunities (p. 81). How core competency is defined for an organization's research frames the ongoing discussion of the construct (Drejer, 2002, p. 97). Adopting a similar stance on a firm's core competency, Freiling's (2004) definition provides clear language that considers repeatable, learning based, and non-random enabling capabilities (p. 30). The innovative stance taken by Freiling (2004) and subsequent competency based researchers extends Sanchez \& Heene's (1997) theory to recognize the measurable attributes of the strategic and cognitive abilities of managers (p. 313). Subsequently, evaluating the ability to define innovation through the lens of leadership development competencies offers a perspective of prevailing innovative workforce capabilities.

Developing innovative competency supports the strategic leadership direction as well as a firm's competitive aims. Often, organizations struggle in their attempts to link leadership development and use innovation in support of building leadership competencies. For example, NEC Corporation managers signaled an understanding of the strategic need to build future workforce leadership competencies by deciding to address building needed capabilities in the next generation of leaders (Prahalad \& Hamel, 1990, p. 89). Accordingly, defining enabling leadership building capabilities that focus on developing millennials includes managing change, building competencies, and mending relationships in the workplace. This construct is under study by current generational theorists (Gentry et al., 2011, p. 39; Kupperschmidt, 2000). Moreover, Gentry et al.'s comparison of sixteen capacity building practices for three generations highlights the practical relational significance for leadership development (p. 39). These area practices correspond with many innovator competency factors that serve to extend the framework for developing future leaders.

\subsection{Generational Cohort Theory—Defining Generation}

What ultimately constitutes a generation varies among contemporary generational theorists. The more traditional interpretation defines generation cohorts by shared birth years, age, location, and common life experiences at critical stages of development (Kupperschmidt, 2000, p. 66). Describing a cohort as a group of individuals born at the same time who are presumed to be similar as a result of shared experiences, Parry \& Urwin (2011) distinguish these individuals from other cohorts by chronological proximity to events and other drivers of difference (p. 84). Likewise, other seminal writers leverage Howe \& Strauss' (2007) early definition of a generation to characterize cohorts as a group of individuals with similar age parameter classifications (Costanza, Badger, Fraser, Severt, \& Gade, 2012; Kaye, 2012). 


\section{Macrothink}

While theorists from the fields of management and sociology tend to focus on time, life stage, and period generational effects, this paper aligns with Kupperschmidt's more broad-based practitioner interpretation of generational cohort theory. Figure 1 illustrates Howe \& Strauss' descriptions of generational cohort characteristics. In representing each cohort as a continuous generational cycle, the theoretical framework depicts the authors' argument that millennials will transform into deeply engaged leaders poised to revitalize the workplace and fill roles vacated by succeeding generations (Howe \& Strauss, 2007, p. 14). Use of generational cohort theory's workplace personal attributes, rather than age, time, and period effects, better supports a study attempting to examine innovator competencies that influence leader development of millennials.

Leadership development is a principal concern as organizations adapt the model used to address innovation for the 21st-century workforce. Day, Fleenor, Atwater, Sturm, \& McKee’s (2014) systematic review reveals that the process of leadership development starts at a young age, involves the application of numerous skills, and includes a perspective of developing needed competencies (pp. 79-80). The authors' research overlooks a review of the genetic basis of leadership; consequently, they missed an opportunity to assess cross-cultural leadership capabilities that define competencies that might be attributable to generational rather than multi-cultural factors (Day et al., 2014, p. 80).

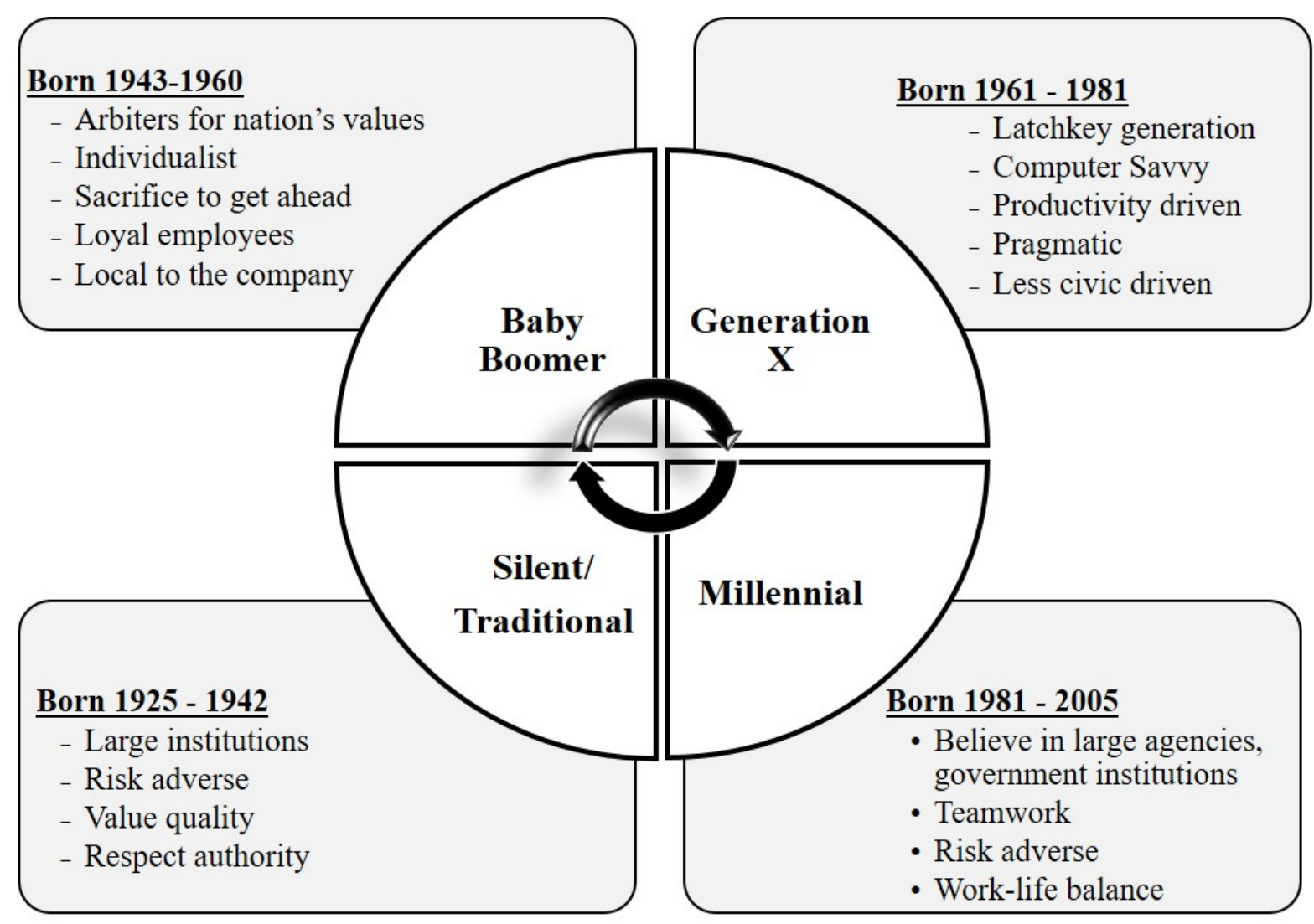

Figure 1. Generational workplace characteristics summary 
Dynamic of four generations in the workplace: Silent/veteran, baby boomers, Generation X, and millennials. Adapted from content in "The Next 20 Years: How Customer and Workforce Attitudes Will Evolve,” by Howe \& Strauss (2007, Harvard Business Review, 85(7/8), pp. 41-52. Copyright 2007 by HBR).

\subsection{Why Competency Matters for Innovative Leadership Development}

Research that consider sage as a variable recognizes that generation factors in the leadership development paradigm. Kubiatko (2013), Marcinkus Murphy (2012), and Venkatesh, Croteau, \& Rabah's (2014) research offer a more contemporary assessment of the relationship between competency and innovation. Examining workplace skills and competencies through the lens of Schumpeter's (1939) economic framework, Prahalad \& Hamel's (1990) competencies of a firm, and Day et al.’s (2014) practices underpin a review to understand how innovation can influence the process of developing leaders. To extend technological and innovation theory requires purposeful analysis of prevailing works of contemporary thought leaders. To that end, factoring generation, specifically cohort characteristics, aligns with building competencies for developing millennial leaders. Moreover, the current research expands the theoretical framework to support a firm's ability to sustain a competitive advantage by adopting a more organizational view of innovation as a core competency in the firm.

The current view of competency theory transcends early psychological and economic perspectives. In reviewing the early theory, building disciplines from the economic foundation provides an understanding of the development of modern-day competency-based management research. By adopting Day's (2001) approach and Gentry et al.'s (2011) viewpoint on leadership development, this study's broader view of competency embraces capabilities associated with developing leaders through the lens of generational characteristics. Gentry et al.'s (2011) study supports a firm's sustained competitive advantage through leadership development practices that build competencies. In summary, Gentry et al.'s research reveals competencies that promote innovative leader development. This study presents an opportunity to examine building millennial capability through the lens of Prahalad \& Hamel's (1990) competency theory by mapping the findings with best practices for developing millennial leaders (Gentry et al., 2011).

Furthering research and practice is key to fostering an innovative workplace environment. Day et al.'s (2014) subsequent review of the evolution of leadership development over the past two decades identifies significant advances in leader development approaches (p. 63). Although comprehensive, Day et al.'s research did not address how and whether age is a factor in developing leaders, the important behaviors, or competencies required when developing an individual (p. 80). In addressing the gap for developing leaders, this paper uses Day's (2001) early reviewed practices to frame the boundaries of the conceptual framework. In particular, a framework that considers ages and generation a variable supports Day et al. (2014) and Gentry et al. (2011) research. As such, exploring the evidence through a systematic review bridges the research gap and conceptualizes key practices and approaches by deconstructing factors that promote leadership development (Day, 2001; Day et al., 2014). Principally, introducing age as a moderating variable refines the original relationship between 
innovator competencies to offer a reference point for best practice approaches to contemporary leadership development programs.

Core competency and generation are elements to consider and examine along a continuum of capability factors. According to Xavier (2007), the core competencies for leaders include visionary guidance, business or technical expertise, and interpersonal skills (p. 348). Visionary leadership involves the ability to be creative and innovative and demonstrate an aptitude to generate new ideas (Xavier, 2007, p. 348). In fact, innovative technical expertise embraces a business acumen with an understanding and technological savvy attributable to many millennials (Gentry et al., 2011; Xavier, 2007). In developing the next generation of leaders, the interpersonal skills associated with mentors can engender an ability to coach others and provide feedback to enhance individual development in others (Xavier, 2007, p. 349). Therefore, a multitude of competencies can be associated with developing leaders (Day, 2001; Day et al., 2014). For example, the $360^{\circ}$ assessment tool supports gap analysis when identifying potential candidates for leader development when 12-25 potential frequent personal contacts at all levels can assess an individual via a survey (Xavier, 2007, p. 345). Another valuable tool, coaching, is mostly effective for developing people skills and executive position competencies (Xavier, 2007, p. 345). However, this current research targets a review of competencies associated with reverse mentoring and information communication technology (ICT) to examine those practices that most align with the characteristics touted as millennial proclivities (Howe \& Strauss, 2007).

\subsection{Innovator Competency and Millennials Leaders}

As a cohort, millennials at work are unlike earlier generations. With a different view of the world and understanding of personal and professional success, preceding generations tend to misunderstand the millennial motivation in today's workplace. Describing what millennials desire from their jobs, Diane Speigle, CEO of End Result, pinpoints coaching and mentoring, collaborating, measuring, and motivating as key elements to harness this generation's unique competencies, perspectives, and strengths (Brack, 2012, p. 7). Additionally, Deloitte's recent study (DTTL, 2015) avers that current organizations fail to make "full use" of the skills and competencies for the millennial generation (p. 8). Millennials look to business to drive innovation and thereby enable competitive progress for the organization by considering competencies that promote, measure, and encourage coaching and mentoring (Brack, 2012, p. 11; DTTL, 2015, p. 2). Using Day’s (2001) conceptual approach to leadership development can support a review of mentoring and the learning associated with ICT competencies as predominate millennial workplace predilections. As a result, this current study explores how ICT and reverse mentoring influence leadership development of millennials.

\subsubsection{Information Communication and Technology as an Innovative Competency}

Millennials are characteristically identified as technically savvy in their use of technology and are more apt to use online tools extensively in their daily life. As emerging technology leaders, millennials will comprise 75\% of the workforce by the year 2025 (DTTL, 2015, p. 2). Many millennials want to work for companies that nurture innovative or creative thinking so that they can develop competencies and positively contribute to the organization. Kubiatko 
(2013) and many other innovation scholars recognize millennials as technologically confident and competent individuals with a strong sense of self in both in and out of the workplace. For example, Venkatesh et al.'s (2014) research theoretically links new methods for teaching with learning digital technology (p. 113). ICT use is often categorized as self-governing and independent (Venkatesh et al., 2014). Shear et al.'s (2014) research examines opportunities for the development of the 21st Century Learning Design (21CLD) competencies in instruction through ICT (p. 86).

The 21CLD global professional development program highlights the merits of ICT for instructional innovation. In building 21st century competencies through innovation integration, this leadership development program demonstrates how processes can be extended to support innovative teaching for millennials (Shear et al., 2014, p. 86). Using an empirically-derived theory of self-regulated learning, Venkatesh et al.'s (2014) notion of ICT competencies suggest that when students perceive themselves as being ICT competent, they typically attribute the effects to their capability development (p. 113). Clearly, ICT can effectively leverage the millennials' technical proclivity to contribute positively to their leadership development.

\subsubsection{Reverse Mentoring as an Innovative Competency}

Most formal mentoring programs align with the silent/veteran and baby boomer preferences. In general, traditional programs are typically planned, assigned, maintained, and monitored by the organization (Day, 2001, p. 591). In contrast, Chen's (2013) study presents a less formalized program where IT competent millennials flourish as copious innovative thinking and risk-taking team players (p. 208). Depending upon the strength of their skills, shifting responsibility for organizing mentoring from the executive to the employee presents opportunities for millennial leader development (Meister \& Willyerd, 2010). In this manner, cross-generational relationships develop through reverse mentoring: pairing of a junior or mentor employee to share expertise with a more senior colleague as the mentee (Marcinkus Murphy, 2012, p. 549). Subsequently, innovative ways to encourage learning promotes an environment to develop future leaders.

More recent social-exchange theory researchers argue the merits of reverse mentoring and suggest that the success of individuals in developing competencies are, in fact, enablers of organizational innovation (Marcinkus Murphy, 2012, p. 552). Likewise, Chaudhuri \& Ghosh (2012) claim that the firms most effective in managing their multigenerational workforce may realize a competitive edge when reverse mentoring is used as a social exchange tool (p. 70). With reverse mentoring capitalizing on millennial capabilities, it follows that enhancing individual networks, increasing power, and encouraging knowledge sharing supports millennial leadership development (Chaudhuri \& Ghosh, 2012; Marcinkus Murphy, 2012). Exposing the mentee to multi-generational perspectives helps to build capacity through learning and leader development. As a leadership development approach, reverse mentoring offers a cost-effective and innovative way to bridge developmental gaps between generations (Marcinkus Murphy, 2012, p. 550). Accordingly, reverse mentoring can be a forward-thinking organizational tool that fosters cross-functional generational learning in 
addition to supporting the millennial preference for a continuous learning environment (Marcinkus Murphy, 2012, p. 56). With knowledge sharing extending to transferring unique skills and competencies, reverse mentoring offers positive predictor opportunities for millennial leadership development.

\subsection{Innovation and 21st Century Leadership Development}

Research suggests that stereotypical generational differences among workers challenge many organizations. However, given the mixed messages provided by existing evidence, it is debatable whether organizations can understandthe influence of generational differences in workplace values, behaviors, and attitudes, along with the impact on developing leaders (Becton, Walker, \& Jones-Farmer, 2014, p. 175). Millennials bring continuous learning, team playing, collaborating, critical thinking, and socially conscious capabilities to an organization (Brack, 2012, p. 4). Brack's view of what millennials bring to an organization fills the skills gap identified in Gentry et al.'s (2011) leadership practices research. Specifically, leading employees, change management, and building and mending relationships reveal competency gaps as practitioners create an environment to develop innovative millennials (Gentry et al., 2011, p. 48). Filling this void is the challenge facing leaders in the 21 st century workplace.

Assuming that the competitive landscape will be complex and replete with competitive threats and opportunities, leadership development will require a knowledge base that embodies innovativeness. Given that millennials interpret life experiences through enduring values, attitudes, and life experiences, committing to organizational investment in millennials is essential for an innovative firm's competitive advantage (Kupperschmidt, 2000). Hence, building leadership competency in millennials is paramount for innovative organizations. Furthermore, offering specialized programs designed to support specific developmental requirements that factor in generational growth and development is a unique and strategic innovative competency for organizations.

Table 1. Linkages between competencies and capabilities

\begin{tabular}{|l|l|l|}
\hline $\begin{array}{l}\text { Leadership Development Capabilities } \\
\text { Gentry, Deal, Griggs, Mondore, \& Cox (2011) }\end{array}$ & $\rightarrow$ & $\begin{array}{l}\text { Innovator Competencies } \\
\text { Boyd (2011) }\end{array}$ \\
\hline Creativity & $\rightarrow$ & $\begin{array}{l}\text { Resourcefulness and being a strategic thinker and } \\
\text { problem solver }\end{array}$ \\
\hline Enterprising & $\rightarrow$ & $\begin{array}{l}\text { Decisiveness and taking action and calculated } \\
\text { risks }\end{array}$ \\
\hline Forecasting & $\rightarrow$ & $\begin{array}{l}\text { Participative and communicating/building } \\
\text { consensus }\end{array}$ \\
\hline Integrating Perspectives & $\rightarrow$ & $\begin{array}{l}\text { Change management and using effective } \\
\text { strategies to facilitate and overcome resistance to } \\
\text { change }\end{array}$ \\
\hline Managing Change & & \\
\hline
\end{tabular}


Several researchers align innovator competencies and predominate workplace leadership practices (Boyd, 2011; Gentry et al., 2011, p. 43). In describing the relationship, they offer a conceptual view of the linkages between core competencies attributable to innovation and millennial leadership development approaches. The conceptual representation (Table 1) adapts Boyd's description for innovator competencies and how it potentially links with each competency identified by Gentry et al.'s leadership development capabilities. Understanding how innovation aligns with developing needed competencies underscores an essential management paradigm. While some of Boyd's linkages present a logical relationship between innovation competencies and Gentry et al.'s millennial leadership practice competencies, most concepts represent a direct relationship. For example, Boyd's fostering creativity, integrating perspectives, and managing change innovator competencies closely parallel leadership development practices. Similarly, Gentry et al.’s leadership practices under investigation for being a quick study align with Boyd's enterprising and tech-savvy innovator competency characteristics. Lastly, Boyd's innovative forecasting competency, specifically when managing the future and evaluating associated risks, aligns with Gentry et al.'s decisiveness leadership practice. Though Gentry et al. identify 16 distinct leadership development practices, this review purposefully highlights the relationship between identified innovator competencies from the derived millennial leadership development practices.

\section{The Study}

This study is an effort to extend previous research on validating innovator competencies with an aim to determine the extent to which ICT and reverse mentoring influence leadership development. This study uses age as a moderating variable tofurther seek and ascertain whether generation factors in developing leadership competencies for the millennial cohort. Specifically, the following two propositions are used to drive this research to examine: How do leadership development competencies influence innovative workforce capabilities development for the millennial cohort?

Proposition 1: Technology, specifically ICT, is positively related to millennials' leadership development as an innovation activity.

Proposition 2: Reverse mentoring is positively related to millennials' leadership development as an innovation activity.

\section{Research Methodology}

When examining what is known about a policy or practice and critically appraising existing research, performing an REA offers one way to evaluate relevant evidence (Civil Service, 2010; Gough, Oliver, \& Thomas, 2012, pp. 39-40). Basing this review on the REA approach provided a methodology to search and identify research in a systematic manner. While the depth is limited by the selected search terms as well as the breadth of identified sources, the REA offers rigor and is useful in quickly gathering evidence to determine the need for future research. In conducting this review, the subsequent stages were followed: research planning and rationale, research identification, selection of primary studies, and data synthesis; all 
constitute the process used to adhere to the REA study methodology (Civil Service, 2010; Gough et al., 2012, pp. 39-40).

\subsection{Research Planning, Identification, Selection, and Rationale}

A primary objective of this study was to examine leadership development through the lens of competency-based theory, more specifically, the applied ontologies included in the process of competency theory and how the process occurs within generations. The search to establish the relationship between competency practice approaches and innovative leadership development starts with defining the parameters of the study. This effort explores whether innovative competencies inform millennial leadership development and build capabilities that have a potentially high probability of supporting the competitive requirements of today's firms.

An electronic keyword search for empirical studies conducted during March 2015 of UMUC's One Search library's database used the terms "millennial” and "reverse mentoring" and "millennial" and "ICT" to establish the boundaries for the search. Table 2 identifies the research keywords that included the wildcard "*” with terms "leader* and develop*" combined with cohort or cohort theory, competency or competenc*, and "innovation*" further refined the search. Combining these terms with Boolean operand "AND" and "OR" synonyms and proximity, as in (leader* n3 develop*) AND (competenc* or competency), generated the bulk of data. Targeted searches provided an additional subset of data. Additional qualifiers limit included studies of English and peer-referred publications from the year 1990 onward.

Table 2. Electronic resources and research keyword

\begin{tabular}{|c|c|c|c|}
\hline \multicolumn{4}{|l|}{ Electronic Resources } \\
\hline \multicolumn{4}{|l|}{ UMUC One Search } \\
\hline $\begin{array}{l}\text { Business Source Complete } \\
\text { CINAHL } \\
\text { PsycINFO } \\
\text { CINAHL Compete } \\
\text { Library, Information Science \& } \\
\text { Technology } \\
\text { Science Direct }\end{array}$ & \multicolumn{2}{|c|}{$\begin{array}{l}\text { Science Citation Index } \\
\text { JSTOR Journals } \\
\text { SocINDEX with Full Text } \\
\text { Social Science Citation Index } \\
\text { Master FILE Premier } \\
\text { Professional Development } \\
\text { Collection }\end{array}$} & $\begin{array}{l}\text { Teacher Reference Center } \\
\text { ERIC } \\
\text { Environment Compete } \\
\text { MEDLINE } \\
\text { Arts \& Humanities Index } \\
\text { Political Science Complete } \\
\text { Business Insights; Essentials }\end{array}$ \\
\hline \multicolumn{4}{|l|}{ Additional Resources } \\
\hline Emerald & \multicolumn{2}{|l|}{ Google Scholar } & Academy of Management \\
\hline \multicolumn{4}{|l|}{ Research Keywords } \\
\hline Theoretical Keywords & & \multicolumn{2}{|c|}{ Conceptual Keywords } \\
\hline $\begin{array}{l}\text { Competency Theory } \\
\text { Competency Based Theory } \\
\text { Generational Cohort Theory } \\
\text { Cohort Theory }\end{array}$ & & \multicolumn{2}{|c|}{$\begin{array}{l}\text { Leadership Development } \\
\text { Innovation / Innovator } \\
\text { Millennial } \\
\text { Reverse Mentoring } \\
\text { Information Communication Technology }\end{array}$} \\
\hline
\end{tabular}

While most articles addressed competency or competency-based theory (Figure 2), recent 
publications with findings or discussion that identified direct linkages to generational cohort theory (Figure 3) implications comprised the final subset for analysis. Selecting publications based on the validity of generalized inferences supports the external validity of the research and implications for other populations.

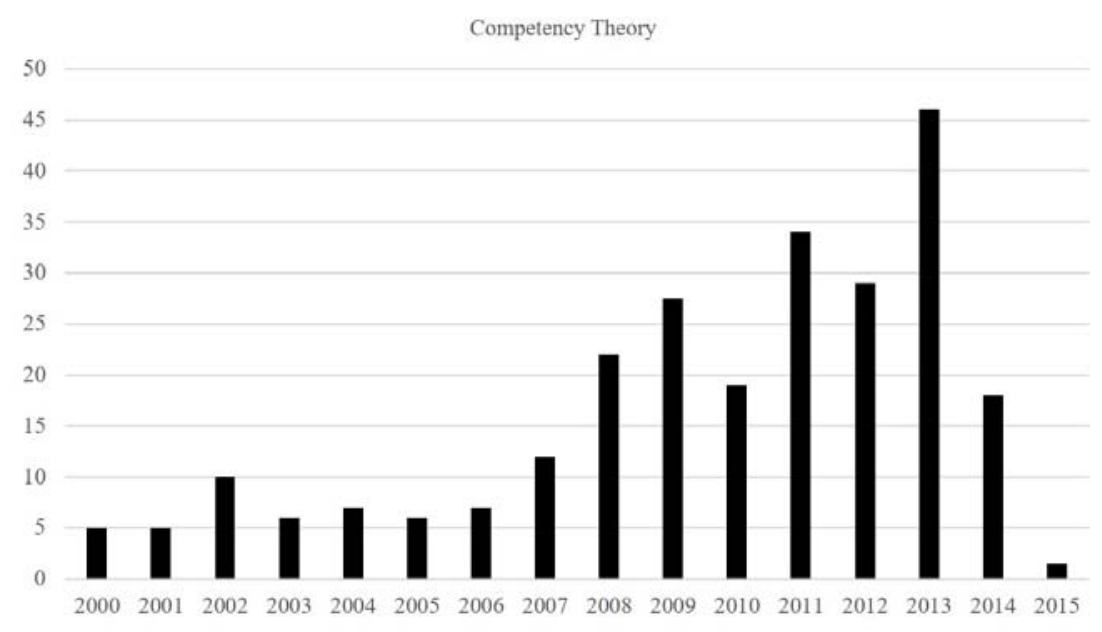

Figure2. Citation ranges, competency-based theory

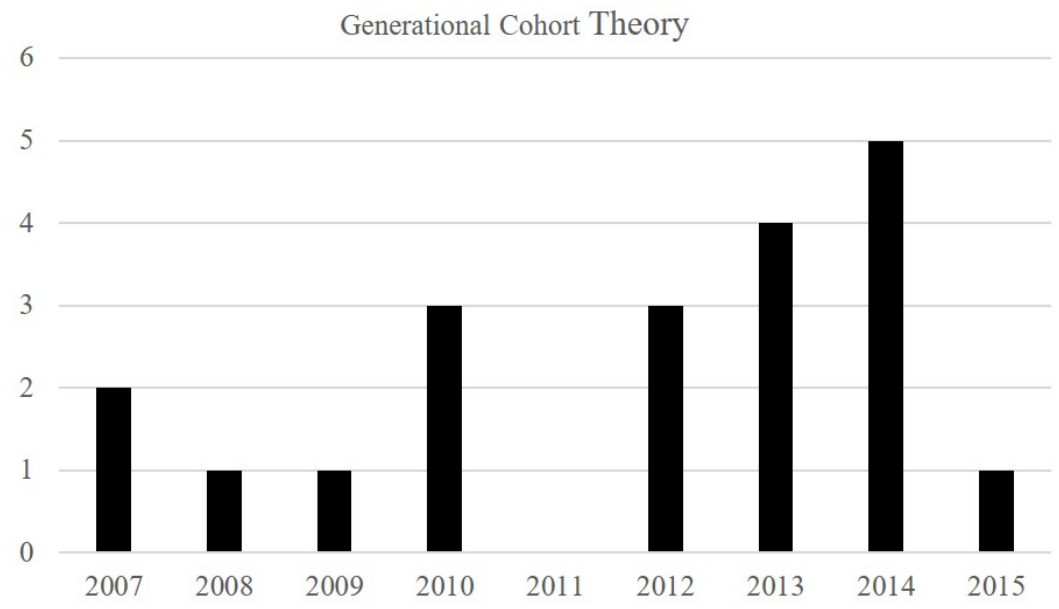

Figure 3. Citation changes, generational cohort theory

To that end, the excluded publications lacked a clear relationship to the study topic, a link to leadership development practices, relevance to innovation for firms, an empirical basis, or a linkage to millennials. The REA sources depicted in Figure 4 outlines the final inclusion and exclusion criteria. Figure 4 also highlights the REA process that resulted in eleven included primary publications illustrated in the PRISMA diagram. 


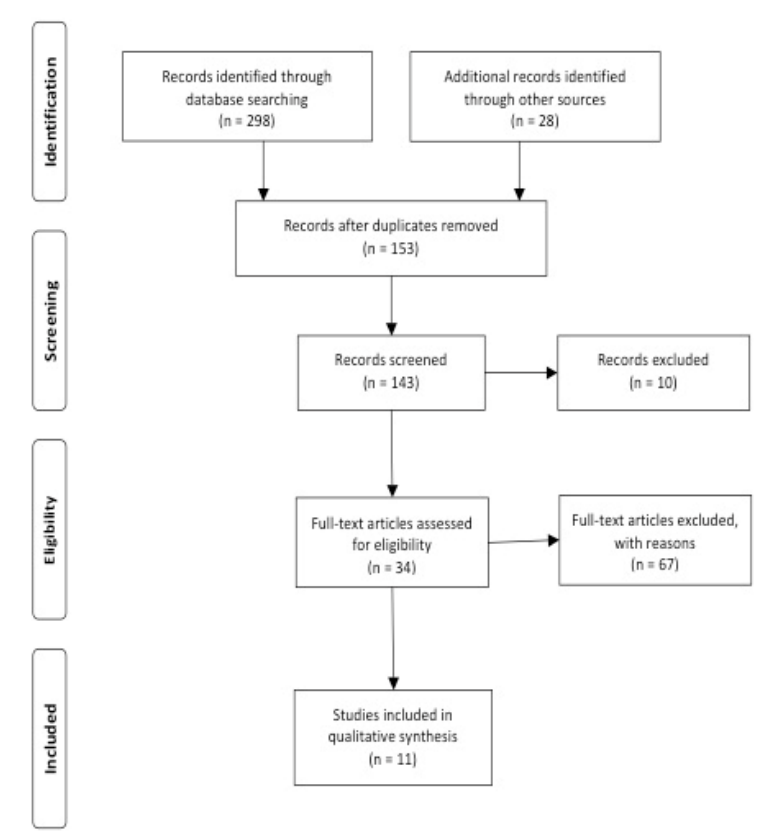

Figure 4. PRISMA flow diagram

\subsection{Data Synthesis}

After a thorough review of the selected publications, direct extraction of data targeted study characteristics, findings, and workplace competencies from each publication. Table 3 summarizes the characteristics and findings used for synthesizing data of the included publications. The relevant findings section, bolded to denote the relationship between the findings, resulted in derived themes identified during the synthesis.

Table 3. Included studies, summary characteristics and contribution to identified themes

\begin{tabular}{|l|l|l|l|}
\hline $\begin{array}{l}\text { Contributing } \\
\text { Authors }\end{array}$ & $\begin{array}{l}\text { Research } \\
\text { Method }\end{array}$ & Data Collection \\
$\begin{array}{l}\text { Brown \& } \\
\text { (2010) }\end{array}$ & Qualitative & $\begin{array}{l}\text { Results in Relation to } \\
\text { Reverse Mentoring and ICT }\end{array}$ \\
\hline $\begin{array}{l}\text { Chaudhuria } \\
\text { \& Ghosh } \\
\text { (2012) }\end{array}$ & Systematic & $\begin{array}{l}\text { Literature } \\
\text { Review }\end{array}$ & $\begin{array}{l}\text { The range of ICT skills and experience of the students } \\
\text { within 'the millennial generation' should not be assumed. It } \\
\text { is both diverse and homogeneous in terms of computer } \\
\text { experience. }\end{array}$ \\
& $\begin{array}{l}\text { Inconclusive evidence about the work outcomes of reverse } \\
\text { mentoring for the multigenerational workforce; however, } \\
\text { pairing Millennials and Boomers in developmental } \\
\text { partnerships can help human resource professionals } \\
\text { address their respective needs. }\end{array}$ \\
\hline $\begin{array}{l}\text { Chen (2013) } \\
\text { Qualitative }\end{array}$ & $\begin{array}{l}\text { Semi-structured } \\
\text { reviews (N=7 }\end{array}$ & $\begin{array}{l}\text { Before implementing a reverse mentoring program, } \\
\text { organizations should take great effort to prepare employees }\end{array}$ \\
\hline
\end{tabular}




\begin{tabular}{|c|c|c|c|}
\hline $\begin{array}{l}\text { Contributing } \\
\text { Authors }\end{array}$ & $\begin{array}{l}\text { Research } \\
\text { Method }\end{array}$ & Data Collection & $\begin{array}{l}\text { Results in Relation to } \\
\text { Reverse Mentoring and ICT }\end{array}$ \\
\hline & & pairs) & $\begin{array}{l}\text { psychologically for the experience of learning from } \\
\text { colleagues of a different generation. }\end{array}$ \\
\hline Chen (2014) & Qualitative & Survey $(N=158)$ & $\begin{array}{l}\text { Provides organizations with a reference point for } \\
\text { quantitative evaluations when promoting and executing } \\
\text { reverse mentoring; however, study focus was limited to IT } \\
\text { companies which have already adopted reverse mentoring } \\
\text { in Taiwan. }\end{array}$ \\
\hline $\begin{array}{l}\text { Kennedy et } \\
\text { al. (2010) }\end{array}$ & Qualitative & $\begin{array}{l}\text { Survey } \\
(\mathrm{N}=2096)\end{array}$ & $\begin{array}{l}\text { Advanced ICT, power users, are in the minority with males } \\
\text { as early adopters of technology and tools; asserts that } \\
\text { Millennials are far from being a homogeneous cohort. }\end{array}$ \\
\hline $\begin{array}{l}\text { Kubiatko } \\
\text { (2013) }\end{array}$ & Qualitative & Survey $(N=266)$ & $\begin{array}{l}\text { Millennial and the X Generation are different from each } \\
\text { other when it comes to their use of and attitude toward ICT } \\
\text { and Internet. }\end{array}$ \\
\hline $\begin{array}{l}\text { Marcinkus } \\
\text { Murphy } \\
(2011)\end{array}$ & Systematic & $\begin{array}{l}\text { Literature } \\
\text { Review }\end{array}$ & $\begin{array}{l}\text { Reverse mentoring is an innovative and cost-effective } \\
\text { approach for organizations to foster cross- generational } \\
\text { relationships and develop millennial leaders. }\end{array}$ \\
\hline $\begin{array}{l}\text { Narasuman } \\
\text { et al. (2011) }\end{array}$ & Qualitative & Survey $(\mathrm{N}=102)$ & $\begin{array}{l}\text { The Millennial generation is active in engaging with ICT; } \\
\text { while tech savvy, they have little knowledge of how } \\
\text { computers work, how to improve performance, } \\
\text { understanding technological details, etc. }\end{array}$ \\
\hline $\begin{array}{l}\text { Valtonen et } \\
\text { al. (2010) }\end{array}$ & Qualitative & $\begin{array}{l}\text { Questionnaire } \\
(\mathrm{N}=1070)\end{array}$ & $\begin{array}{l}\text { For social networking, there are differences in how } \\
\text { Millennials use software (ICT). }\end{array}$ \\
\hline $\begin{array}{l}\text { van den } \\
\text { Beemt et al. } \\
\text { (2011) }\end{array}$ & Systematic & $\begin{array}{l}\text { Literature } \\
\text { review } \\
\text { ( } \mathrm{N}=7 \text { included) }\end{array}$ & $\begin{array}{l}\text { Instead of one homogeneous generation, there are } \\
\text { subgroups in the levels in the use of ICT, and the meaning } \\
\text { and motives for media use are not well studied nor are } \\
\text { issues associated with Millennial identity (e.g., how } \\
\text { interactive media are useful and influence Millennials). }\end{array}$ \\
\hline $\begin{array}{l}\text { Venkatesh et } \\
\text { al. (2014) }\end{array}$ & Quantitative & $\begin{array}{l}\text { Questionnaire } \\
(\mathrm{N}=14,283)\end{array}$ & $\begin{array}{l}\text { Individual and social use of ICT and the level of student's } \\
\text { individual study and self-regulatory strategy use } \\
\text { significantly contribute to students' satisfaction toward } \\
\text { their courses. }\end{array}$ \\
\hline
\end{tabular}

\section{Conceptual Framework}

A conceptual framework illustrates the relationship between ICT and reverse mentoring practices for developing organizational leadership, innovator competencies, and innovation as (Figure 5). As inputs to the model, Boyd's (2011) creative thinking, forecasting, managing change, integrating perspectives, and enterprising innovator competencies underpin the leadership development of the millennial mentor in supporting organizational innovation. In examining the generational characteristics which align with Day's (2001) research, the analysis includes ICT and reverse mentoring practices that highlight key millennial 
leadership development practices. In suggesting a link between innovator competencies and leadership development, this study examined technology, specifically ICT, and reverse mentoring leadership development practices.

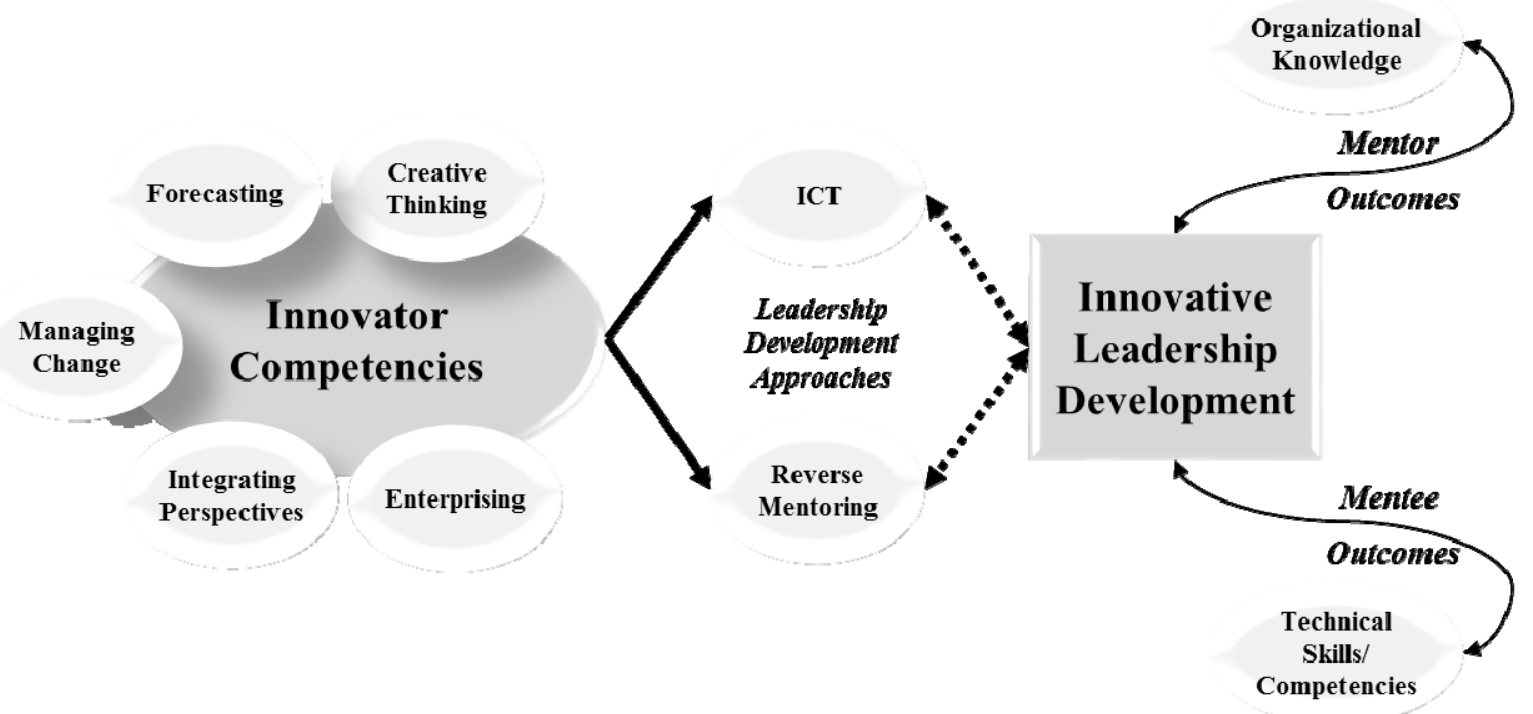

Figure 5. Innovator competencies and leadership development approaches for millennials

Source: Adapted from “Innovator Competency Model” [Web log post], by Boyd, 2011. Copyright 2011 by Innovation Excellence.

As innovative leadership development can be bi-directional and provide lessons learned to improve practices, the directional arrows are represented as dotted lines to indicate both an incoming and outgoing relationship for each construct. In fact, Day et al.'s (2014) review of the advances in leadership development best practices support the concept of innovative leadership development. When millennials serve as mentors, the expected outcomes for the cohort include attaining a deeper understanding of the organization. Likewise, mentoring more senior members of a cross-generational workforce results in enhanced mentee technical skills and competencies (Marcinkus Murphy, 2011). Within the feedback loop, using ICT and reverse mentoring offer innovative competencies that support leader development through practices that reinforce both generations through direct mentor/mentee interactions (Brown \& Czerniewicz, 2010; Chen, 2013; Kubiatko, 2013; Marcinkus Murphy, 2011). While the mentor imparts an increased awareness of the organization using reverse mentoring, the millennial mentee's transfer of technical skills and competencies through ICT reveals pathways for enhancing leadership competencies for this cohort with reverse mentoring. 


\subsection{Results-Comparison of Millennial Leadership Development Competencies}

Syntheses of the included studies reveal several overarching competency themes which describe leadership development of millennials. Specifically, managing change and creative thinking, when coupled with ICT and reverse mentoring leadership development practices, underpin innovative leadership development for baby boomer mentees and millennial mentors. Overall, the research showed a supporting relationship between technology savvy millennials, ICT competencies and reverse mentoring. More importantly, augmenting or replacing traditional lecture-based leadership development modalities with ICT tools offers a blended leadership delivery, supports millennial technological preferences in developing leadership competencies. Together, ICT and reverse mentoring offer leadership development approaches that extend the theoretical framework. More importantly, they support innovative leadership development as a salient opportunity in developing competencies for millennial leaders.

\subsection{Information Communication Technology as an Innovation Tool for Millennials}

Many researchers claim that generations differ from each other in their use and approach to using technology in the workplace. Using inductive statistical methodologies, Kubiatko (2013) and Narasuman et al.'s. (2011) findings align with data from the qualitative studies when it comes to millennials and their attitudes towards ICT. Although deemed tech savvy, Narasuman et al. (2011) argue that there are several weaknesses that require attention when developing millennials. Even van den Beempt's (2011) systematic review identified subgroups that reveal that millennials are not exactly a single homogeneous functioning group within the cohort. In theory, Venkatesh et al. (2014) suggests that digital technology facilitates new methods for teaching and learning (p. 113). While research suggests that this generation actively engages with technology, it does not necessarily align with the rationale cited by generational cohort theorists (Narasuman et al., 2011, p. 74). For this cohort, innovation competencies based on technology is a continuum.

Millennials are typically considered tech savvy; however, weaknesses exist within the cohort as it pertains to their ICT capabilities and knowledge. Often, the millennials' use of ICT tools is self-governing and independent (Venkatesh, 2014). As an example, Venkatesh et al.'s survey-based research, which augments Shear et al.'s (2014) study, adds a clear perspective of ICT and the ability to assess the student's quality of learning. Perception, proficiency, and knowledge of ICT tools are critical and influence the success of ICT integration (Venkatesh et al., 2014, p. 110). By building on Shear et al.'s (2014) notion of ICT competencies, Venkatesh et al.'s research adds to a student's awareness of technological capabilities. Subsequently, the perceived cognizance contributes to influencing their overall learning. Clearly, ICT can positively support millennial competency development. Within this framework, ICT is associated with millennial leadership development as an innovation activity. 


\subsection{Reverse Mentoring as an Innovation Tool for Millennials}

Creative thinking combines industry vision and builds competencies that promote developing leadership capability. In this way, promoting cross-generational relationships through reverse mentoring presents an innovative way to develop future leaders (Marcinkus Murphy, 2012, p. 549). By pairing junior employees with more senior colleagues, Marcinkus Murphy found that reverse mentoring capitalizes on millennial capabilities, enhances individual networks, and encourages knowledge sharing. Chen's (2013) analysis of the mentoring case study makes a salient research point that addresses organizational readiness.

According to Chen (2013), the employee's professional effectiveness and learning is lessened when a concerted effort has not been made to prepare the organization for the psychological experience of cross-generational learning. While reverse mentoring offers many of the same benefits as traditional mentoring, several nuances make this leadership development approach a welcomed management alternative. For example, a technically astute millennial mentor providing the baby boomer mentee with a more practical digital learning experience can facilitate a more professional knowledge and a learning experience than that previously offered in a more traditional setting (Chen, 2013, p. 203). Building on his earlier study, Chen's (2014) in-depth systematic review advances the notion of mentoring as an innovative approach for developing millennials. With findings similar to Marcinkus Murphy (2012), Chen's (2014) research outcomes support mentor enhanced technical skills through millennial mentees who also benefit from the relationship by developing key leadership competencies.

Exposing the more senior mentee to multi-generational and millennial perspectives helps to build technical competencies through learning and leader knowledge sharing. Through knowledge sharing, reverse mentoring can be a highly innovative organizational tool. In addition to fostering cross-functional generational learning, reverse mentoring supports a millennial preference for a continuous learning environment (Marcinkus Murphy, 2012, p. 56). Furthermore, it is most certainly a purposeful tool that leverages expertise akin to both generations (Chaudhuri \& Ghosh, 2012, p. 55). A review of reverse mentoring outcomes for baby boomers and millennials suggests a positive relationship that reinforces developing innovative leaders.

\section{Discussion}

Exploring what is distinctive about leadership development through the lens of innovative competency for the millennial cohort frames the boundaries for this review. The review of the 11 synthesized studies that suggest ICT and reverse mentoring competencies can influence workforce capabilities for millennials. The existence of a moderately positive association between innovative competencies and millennials within the broad definition of leadership development competencies, coupled with evidence of a relationship between millennials and reverse mentoring competency, and applicability of ICT capabilities might be underrated. In fact, these factor as some of the more significant millennial competencies in developing leaders within this cohort. Taken independently, none of the studies prove or disprove the 
notion that competencies moderated by generational characteristics influence millennial leadership development.

Conversely, for most of the studies, the derived results suggest other best practices that might influence innovative workforce capabilities for millennial leadership development. For example, networking and other forms of collaborative social networking might combine with ICT and reverse mentoring in supporting developing leadership competencies. As indicated in Gentry et al.'s (2011) and Chen's (2014) earlier work, it is strategically prudent for organizational leaders to use generational characteristics to attract, recruit, identify, retain, and develop the future leaders. Developing a broad-based view that embraces innovative competencies maximizes the prospective development of leaders. Ultimately, this development includes millennials as a viable option to fill the impending critical leadership void.

\subsection{Practical Implications}

It is important for millennials to embrace the leadership development competencies that position them to serve as leaders and managers in the future. According to Zenger (2012), most individuals enter formal leadership programs at age 42 (para. 4). Consequently, managers will need to provide effective leadership development support that creates opportunities for successful leadership development. Many organizations are positioning innovative millennials for roles that include increased leadership, responsibility, and accountability opportunities. Millennials, the human resource management's (HRM) "capital” for a firm, are both financial and investment resources. Given the forecast that fore shadows baby boomers retiring in the next 10-15 years, timing the transition of leadership is critical for organizational leaders. With this in mind, it is important that millennials develop the requisite skills to lead and manage. Therefore, a more in-depth review and understanding of the competencies required for millennials to effectively lead is paramount.

The inculcation of leadership competencies through reverse mentoring makes developing innovative leaders through this practice more desirable for many organizations. An environment that avails senior staff to millennials promotes a much-needed leader development/mentorship. In turn, this arrangement satisfies one of the present day challenges faced by leaders and managers of senior generational cohorts. Understanding how best to use technology in developing the next generation of leaders presents a real barrier when developing leaders. Removing the perceived non-accessibility to subordinates is one of the first steps to developing innovative leaders. Second, acquiring specific competencies such as reverse mentoring, networking, and coaching may assist leaders/managers in supporting millennials with practices that complement competency skills inherent for this cohort. Reverse mentoring offers a clear pathway that taps into the expertise and technological awareness of the millennial workforce (Marcus Murphy, 2011, p. 550). While Kennedy, Judd, Dalgarno, \& Waycott (2010) present compelling evidence that millennials are far from homogeneous, their research supports the prevailing reverse mentoring and ICT theorists' findings and patterns of effective technology use (p. 341). Indeed, ICT and reverse mentoring offer innovative ways to develop leaders. 
HRM should take advantage of leadership development competencies to assist in building effective workplace leader programs. Strengthening practices and systems that satisfy the complex needs of a multi-generational workplace includes innovative competencies. For HRM to be successful, systems and programs should include talent, collaborative, and knowledge management practices that support career management requirements. Additionally, corporate executives, without a doubt, need leader development innovator competencies that help create effective leadership strategies that facilitate clear and understandable articulation of the organization's vision and mission. As such, embracing innovator competencies at this level may be a vehicle that enables executives to achieve a competitive edge as well as keep abreast of the latest industry technology advancements.

\subsection{Limitations}

This study has several limitations that offer opportunities for future research. With the U.S. Census Bureau reporting (U.S. Department of Commerce, 2014) the current size of the baby boomer generation in the American workforce as nearly 66 million, managers will need to fill the baby boomer leadership voids with the 54.7 million millennials in the current workforce (U.S. Department of Commerce, 2014). Clearly, millennials represent a growing and varied group of leaders emerging at all levels of their respective organizations. First, the diversity of millennials as a group limits the ability for comparison across group types. Future research that targets millennials by country of origin, industry, education, and organization size may support the aims to understand innovation impacts on competencies for emerging leaders. The innovative competency focus centered on reverse mentoring and ICT. A more in-depth search that targets the networking competencies and collaborative millennial skills would provide measures to capture a broader range of leadership development competencies that inform leadership development based on generational characteristics (Day, 2001; Day et al., 2014).

The selected studies present a conservative qualitative view of millennial competencies across a variety of industries that do not consider culture, gender, and other demographical data as a limiting factor. A more robust systematic review may offer measures to assess the millennial cultural, gender, or skill-sets that embrace the innovative practices that develop leadership in the workforce. Moreover, empirical research that examines competencies able to build on generational cohort theory supports the aims of this study to understand how leadership development competencies might influence building innovative millennial leaders. Hence, identifying outcomes based on millennial cohort characteristics that factor personal attributes or specific cohort experiences, such as economics, politics, and customs, exemplify the REA limitations that a more comprehensive research study might reveal.

\section{Conclusion}

The purposeful review of innovative-based competencies and leadership development practices is required strategically to support organizations in today's competitive contested marketplace. Millennial innovative competencies, specifically ICT and reverse mentoring skills, appear to affect the development of the next generational workplace cohort when supported by leadership development. In this study, ICT and reverse mentoring influenced 
developing leadership competencies in concert with enterprising, integrating, forecasting, and managing change opportunities when developing innovative millennial leaders. The potential to facilitate and influence leadership development of millennials in organizations through cultivating innovator competencies provides the competitive edge that many organizations seek. Defining the more significant pathways to expedite innovative capabilities for millennials helps to develop their competency profiles, and ultimately promotes the firm's competitiveness, thereby supporting how firms might use innovation in the leader development process.

Organizational leaders face an impending challenge to select, identify, and develop the leaders to fill anticipated leadership voids. Generational workforce change is inevitable. Given the looming exodus from the workforce of silent/veterans and baby boomers, today's leaders must work to build a workforce that is mindful of building leadership talent that embraces the organization's innovative requirements. Building a competitive edge by developing innovative millennials, the next generation of senior leadership is a logical and prudent next step in understanding how best to address needed competencies at all levels of an organization. However, the data to support this premise are questionable. Not with standing an emerging need to define innovative competencies and leadership development, it would be presumptuous to exact a direct causal relationship between the constructs. Making this claim requires considerable empirical research. Indeed, additional primary data targeting the millennial cohort is required to define the significance of innovative competencies in the development of leaders. The millennial's proclivity for creative thinking, enterprising ingenuity, and managing change through teamwork offers a logical step in developing innovation for future leaders. Further definition of the boundaries between the millennial capabilities derived from identified innovative competencies may reveal whether reverse mentoring and ICT best practices extend to developing leadership competencies needed in future leaders.

\section{References}

Barsh, J. (2008). Innovative management: A conversation with Gary Hamel and Lowell Bryan. McKinsey Quarterly, $1 . \quad$ [Online] Available: https:/socialknowledge.files.wordpress.com/2007/10/hamel-future-of-management.pdf

Becton, J. B., Walker, H. J., \& Jones-Farmer, A. (2014). Generational differences in workplace behavior. Journal of Applied Social Psychology, 44(3), 175-189. http://dx.doi.org/10.1111/jasp.12208

Boyd, D. (2011). Innovation competency model [Web log post]. [Online] Available: http://www.innovationexcellence.com/blog/2011/04/12/innovation-competency-model/

Brack, J. (2012). Maximizing millennials in the workplace. [Online] Available: http://www.kenan-flagler.unc.edu/executive-development/custom-programs/ /media/Files/do cuments/executive-development/maximizing-millennials-in-the-workplace.pdf 
Brown, C., \& Czerniewicz, L. (2010). Debunking the "digital native”: Beyond digital apartheid, towards digital democracy. Journal of Computer Assisted Learning, 26(5), 357-369. http://dx.doi.org /10.1111/j.1365-2729.2010.00369.x

Chaudhuri, S., \& Ghosh, R. (2012). Reverse mentoring: A social exchange tool for keeping the boomers engaged and millennials committed. Human Resource Development Review, 11(1), 55-76. http://dx.doi.org/10.1177/1534484311417562

Chen, Y. (2013). Effect of reverse mentoring on traditional mentoring functions. Leadership \& Management in Engineering, 13(3), 199-208. http://dx.doi.org/10.1061/(ASCE)LM.1943-5630.0000227

Chen, Y. (2014). Examining traditional mentoring functioning scale considering reverse mentoring and the work characteristics of millennials. International Journal of Technology, Policy \& Management, 14(3), 205-219. http://dx.doi.org/10.1504/IJTPM.2014.062931

Civil Service. (2010). Rapid evidence assessment toolkit index. [Web-based resource]. UK Government Web Archive. [Online] Available: http://webarchive.nationalarchives.gov.uk/20140305122816/http://www.civilservice.gov.uk/n etworks/gsr/resources-and-guidance/rapid-evidence-assessment

Costanza, D. P., Badger, J. M., Fraser, R. L., Severt, J. B., \& Gade, P. A. (2012). Generational differences in work-related attitudes: A meta-analysis. Journal of Business and Psychology, 27(4), 375-394. http://dx.doi.org/10.1007/s10869-012-9259-44

Day, D. V. (2001). Leadership development: A review in context. Leadership Quarterly, 11(4), 581-613. http://dx.doi.org/10.1016/S1048-9843(00)00061-8

Day, D. V., Fleenor, J. W., Atwater, L. E., Sturm, R. E., \& McKee, R. A. (2014). Advances in leader and leadership development: A review of 25years of research and theory. Leadership Quarterly, 25(1), 63-82. http://dx.doi.org/10.1016/j.leaqua.2013.11.004

Drejer, A. (2002). Strategic management and core competencies: Theory and application. Westport, CT: Greenwood Publishing Group.

DTTL Global Brand \& Communications. (2015). Mind the gaps: The 2015 Deloitte millennial survey [Executive summary]. [Online] Available: http://www2.deloitte.com/content/dam/Deloitte/br/Documents/about-deloitte/millennial-surve y-executivesummary-2015.pdf

Emeagwali, N. S. (2011). Millennials: Leading the charge for change. Techniques: Connecting Education and Careers, 86(5), 22-26. [Online] Available: http://files.eric.ed.gov/fulltext/EJ925286.pdf

Freiling, J. (2004). A competence-based theory of the firm. Management Revue, 15(1), 27-52. http://dx.doi.org/10419/78932

Gentry, W. A., Deal, J. J., Griggs, T. L., Mondore, S. P., \& Cox, B. D. (2011). A comparison of generational differences in endorsement of leadership practices with actual leadership skill 
level. Consulting Psychology Journal: Practice \& Research, 63(1), 39-49. http://dx.doi.org/10.1037/a0023015

Gough, D., Oliver, S., \& Thomas, J. (2012). An introduction to systematic reviews. Thousand Oaks, CA: SAGE Publications.

Hill, C. W., \& Rothaermel, F. T. (2003). The performance of incumbent firms in the face of radical technological innovation. Academy of Management Review, 28(2), 257-274. http://dx.doi.org/10.5465/AMR.2003.9416161

Howe, N., \& Strauss, W. (2007). The next 20 years: How customer and workforce attitudes will evolve. Harvard Business Review, 85(7/8), 41-52. [Online] Available: http://www.ncbi.nlm.nih.gov/pubmed/17642125

Kaye, B. (2012). Four generations. Leadership Excellence, 29(1), 20. [Online] Available: http://www.lornerubis.com/wp-content/uploads/2012/01/Article-Leadership-Excellence-Jan-2 012.pdf

Kennedy, G., Judd, T., Dalgarno, B., \& Waycott, J. (2010). Beyond natives and immigrants: Exploring types of net generation students. Journal of Computer Assisted Learning, 26(5), 332-343. http://dx.doi.org/10.1111/j.1365-2729.2010.00371.x

Kubiatko, M. (2013). The comparison of different age groups on the attitudes toward and the use of ICT. Educational Sciences: Theory \& Practice, 13(2), 1263-1272. [Online] Available: http://files.eric.ed.gov/fulltext/EJ1017271.pdf

Kupperschmidt, B. (2000). Multigenerational employees: Strategies for effective management. Health Care Manager, 19(1), 65-76. http://dx.doi.org/10.1097/00126450-200019010-00011

Marcinkus Murphy, W. (2012). Reverse mentoring at work: Fostering cross-generational learning and developing millennial leaders. Human Resource Management, 51(4), 549-573. http://dx.doi.org/10.1002/hrm.21489

McClelland, D. C. (1973). Testing for competence rather than for "intelligence.” American Psychologist, 28(1), 1-14. http://dx.doi.org/10.1037/h0034092

McLagan, P. (1996). Great ideas revisited. Training and Development, 50(1), 60-65. [Online] Available: https://www.questia.com/magazine/1G1-18063281/great-ideas-revisited

Meister, J. C., \& Willyerd, K. (2010). Mentoring millennials. Harvard Business Review, 88(5), 68-72. [Online] Available: http://managingmultigenerationalworkforce.pbworks.com/f/Millenium.pdf

Narasuman, S., Yunus, M. M., \& Kamal, A. A. (2011). Net generation student teachers: Howtech-savvy are they? Asia Pacific Journal of Educators \& Education / Journal Pendidik DanPendidikan, 26(1), 71-89. [Online] Available: http://web.usm.my/apjee/webtest/APJEE_26.1.2011/26.1.2011_71-89.pdf 
Northeastern News. (2014). Most business leaders believe innovation is critical for U.S. colleges to remain globally competitive. [Online] Available: http://www.northeastern.edu/news/2014/04/survey-innovation-higher-education/

Parry, E., \& Urwin, P. (2011). Generational differences in work values: A review of theory and evidence. International Journal of Management Reviews, 13(1), 79-96. http://dx.doi.org/10.1111/j.1468-2370.2010.00285.x

Prahalad, C. K., \& Hamel, G. (1994). Strategy as a field of study: Why search for a new paradigm? Strategic Management Journal, 15(supp. 52), 5-16. http://dx.doi.org/10.1002/smj.4250151002

Prahalad, C. K., \& Hamel, G. (1999). The core competence of the corporation. In M. H. Zack (Ed.), Knowledge and Strategy (pp. 235-256). Boston, MA: Elsevier.

Quenqua, D. (2015). Millennials set to outnumber baby boomers. The New York Times. [Online]

Available: http://www.nytimes.com/2015/01/20/science/millennials-set-to-outnumber-baby-boomers.ht $\mathrm{ml}$

Sanchez, R., \& Heene, A. (1997). Reinventing strategic management: New theory and practice for competence-based competition. European Management Journal, 15(3), 303-317. http://dx.doi.org/10.1016/S0263-2373(97)00010-8

Schumpeter, J. A. (1934). The theory of economic development. Cambridge, MA: Harvard University Press.

Schumpeter, J. A. (1939). Business cycles: A theoretical, historical and statistical analysis of the capitalist process (Vol. 1). New York, NY: McGraw Hill.

Schumpeter, J. A. (1950). Wesley Clair Mitchell (1874-1948). The Quarterly Journal of Economics, 64(1), 139-155. http://dx.doi.org/10.2307/1881963

Shear, L. L., Koh, R., Patel, D., Trinidad, G., Chen Kee, T., \& Png, S. (2014). ICT and instructional innovation: The case of crescent girls' school in Singapore. International Journal of Education \& Development Using Information \& Communication Technology, 10(2), 77-88. [Online] Available: http://ijedict.dec.uwi.edu/viewarticle.php?id=1776

U.S. Department of Commerce, Census Bureau. (2014). State Government Employment and Payroll Data: $2013 . \quad$ March [Online] Available: https://factfinder.census.gov/faces/tableservices/jsf/pages/productview.xhtml?src=bkmk

Vanden Beemt, A., Akkerman, S., \& Simons, R. (2011). Considering young people's motives for interactive media use. Educational Research Review, 6(1), 55-66. http://dx.doi.org/10.1016/j.edurev.2010.06.002

Venkatesh, V., Croteau, A., \& Rabah, J. (2014). Perceptions of effectiveness of instructional uses of technology in higher education in an era of Web 2.0. Paper presented at the 2014 47th 


\section{Macrothink}

Case Studies in Business and Management

ISSN 2333-3324 2017, Vol. 4, No. 1

Hawaii International Conference on System Sciences, Waikoloa, HI. http://dx.doi.org/10.1109/HICSS.2014.22

Xavier, S. (2007). Developing emerging leaders: Anew solution to an old problem. Business Strategy Series, 8(5), 343-349. http://dx.doi.org/10.1108/17515630710684457

Zenger, J. (2012). We wait too long to train our leaders [Web log post]. Harvard Business Review. [Online] Available: https://hbr.org/2012/12/why-do-we-wait-so-long-to-trai/

\section{Copyright Disclaimer}

Copyright for this article is retained by the author(s), with first publication rights granted to the journal.

This is an open-access article distributed under the terms and conditions of the Creative Commons Attribution license (http://creativecommons.org/licenses/by/3.0/). 